\title{
Association of Number of Bidders and Minimum Bid Ratio (AEr) with Effect of E-bidding of Different Project
}

\author{
Anjay Kumar Mishra ${ }^{1}$, Megh Bahadur K. C. ${ }^{2}$ \& P. S. Aithal ${ }^{3}$ \\ ${ }^{1}$ Associate Professor, Madan Bhandari Memorial Academy Nepal, Urlabari 3, Morang, Nepal \\ OrcidID: 0000-0003-2803-4918; Email: anjaymishra2000@gmail.com \\ ${ }^{2}$ Engineer, Department of Roads, Government of Nepal, Nepal \\ OrcidID: 0000-0001-5257-5779; Email: kc.megh2048@gmail.com \\ ${ }^{3}$ Professor, College of Management \& Commerce, Srinivas University, Mangalore, India \\ OrcidID: 0000-0002-4691-8736; E-mail: psaithal@gmail.com
}

Area/Section: Project Management.

Type of the Paper: Research Paper.

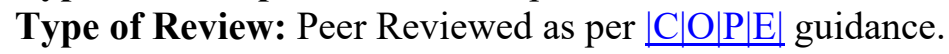

Indexed in: OpenAIRE.

DOI: http://doi.org/10.5281/zenodo.4111956

Google Scholar Citation: IJMTS.

\section{How to Cite this Paper:}

Anjay Kumar Mishra, Megh Bahadur K. C. \& Aithal, P. S. (2020). Association of Number of Bidders and Minimum Bid Ratio (AEr) with Effect of E-bidding of Different Project. International Journal of Management, Technology, and Social Sciences (IJMTS), 5(2), 201-215. DOI: http://doi.org/10.5281/zenodo.4111956

International Journal of Management, Technology, and Social Sciences (IJMTS) A Refereed International Journal of Srinivas University, India.

(C) With Author.

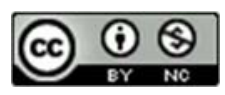

This work is licensed under a Creative Commons Attribution-Non-Commercial 4.0 International License subject to proper citation to the publication source of the work.

Disclaimer: The scholarly papers as reviewed and published by the Srinivas Publications (S.P.), India are the views and opinions of their respective authors and are not the views or opinions of the SP. The SP disclaims of any harm or loss caused due to the published content to any party. 


\title{
Association of Number of Bidders and Minimum Bid Ratio (AEr) with Effect of E-bidding of Different Project
}

\author{
Anjay Kumar Mishra ${ }^{1}$, Megh Bahadur K. C. ${ }^{2} \&$ P. S. Aithal ${ }^{3}$ \\ ${ }^{1}$ Associate Professor, Madan Bhandari Memorial Academy Nepal, Urlabari 3, Morang, Nepal \\ OrcidID: 0000-0003-2803-4918; Email: anjaymishra2000@gmail.com \\ ${ }^{2}$ Engineer, Department of Roads, Government of Nepal, Nepal \\ OrcidID: 0000-0001-5257-5779; Email:kc.megh2048@gmail.com \\ ${ }^{3}$ Professor, College of Management \& Commerce, Srinivas University, Mangalore, India \\ OrcidID: 0000-0002-4691-8736; E-mail: psaithal@gmail.com
}

\begin{abstract}
The purpose of this research is to analyze the relation between the number of bidders versus the minimum bid ratio (AEr)/percentage below the initial engineer's estimate to type and size of project within Road Divisions Butwal and Shivapur. Bidding data of four consecutive fiscal years starting from 072/73 of two Road Divisions which are already completed its procurement stage were analyzed. The percentage below/contract awarded cost is directly proportional or a significant correlation was found with the number of the participated bidder in any project $\mathrm{s}$ of both divisions during the data study period. Bidders have to bid below $20 \%$ of the initial estimate that was found to get a project in hand by contractors and they are willing to bid low for the utilization of resources, types of equipment, manpower, and also to get experiences. This research revealed correlation coefficients between the number of bidders and percentage below engineers' estimates are 0.61 for the Butwal division and 0.67 for the Shivapur division. Correlation coefficients 0.82 and 0.83 was found in Nepalgunj and Mahendranagar. Percentage below engineers' estimate depends on 67 and $69 \%$ on the number of bidders in Nepalgunj and Mahendranagar respectively. E-bidding helped to promote competition along with low bidding. As there is $17 \%$ below with only hardcopy bidding but with e-bid the below percentages rises to $28 \%$ with more number of bidder per project. Improvement in existing offer granting framework with additional capability rules ought to be engaged by doling out the weight in the monitory term, soliciting a technique from the proclamation, upgraded e-offering framework, and affirmation for venture exhibitions of the undertaking before execution. This research would be useful for those who are involving in policy making and governing agencies like Public Procurement Monitoring Office and for making necessary amendments in existing rules.

Keywords: E-bidding, Project Category, Percentage Below Bid, Bid ratio, E-bidding, Hard copy.
\end{abstract}

\section{BACKGROUND :}

Infrastructure development, operation, and maintenance of physical infrastructure are the basic criteria for the development of the nation and the national economy to prosper. Among the various infrastructures, the main backbone for development is transportation infrastructure. Legal provisions are there to make procedures, processes, and decisions relating to public procurement much more open, transparent, objective, and reliable, obtain the maximum returns of public expenditures economically and rationally by promoting competition, fairness, honesty accountability, and reliability in public procurement processes and ensure good governance economically, and rationally (Public Procurement Act, 2007) [1]. PPR (2007) [2] latest revision states the various bidding method \& processes for the procurement and there is a single e-government portal for all the procurement of the Nepal Government called Public Procurement Monitoring Office (PPMO), e-GP I/II (KCM and Mishra, 2019) [3].

Mishra and Malik (2017) [4] set up the danger the board practice of Building development of Nepal should be improved which may expand cost while Contractors are not picking up benefits according to desires however their business is gainful. Collusive, poor, and ineffective public procurement practices 
in Nepal are challenges not only for the country, where the contractor's motive of profit-making is also the root cause of bidding to be ineffective. A low bid award system fosters competition amongst contractors attempting to secure the projects. In Road Divisions, Department of Roads, Bidders/Suppliers bid differently in various categories of contracts according to the nature of works (General road works or structural works or maintenance works) and also knowing the size of works. Numerous researches have been conducted in this area without separating the bidding patterns with bidder's participation effort based on its type and size of works.

The pattern of a low offer with bidders rivalry exists in all classifications of works fluctuating from rock street works, upkeep venture works to bituminous street works including auxiliary segments works yet ranges to get offered close by differs concerning details required and extends in the hand of contractors (Bista \& Mishra, 2019) [5]. The development industry is attempting to apply esteem the board in Nepal for cost-viability as it has discovered a sufficient number of the human asset with A-class temporary workers (Mishra, 2018) [6] however time expansion isn't a special case yet standards of the industry (Mishra, 2018) [7]. Bidders bid for contracts for various reasons like utilization and mobilization of resources, manpower, and also to get experience.

With the promulgation of the federal system, the country is going through three levels of government (Federal, Provincial and Local) with a limited number of technical manpower at the provincial and local level and more and more public infrastructure is to be constructed there in a rapid manner especially in the transport sector. High competition, Collusive practices, abnormal profit-making behavior of contractors, and less manpower to technical supervision from employer leads the contract works to be affected on timely completion within the stated cost, desired quality is not achieved, and effect on other contract performances.

\section{STATEMENT OF PROBLEM :}

Huge monetary speculations (30-50\% of National advancement spending plan yearly) are made in street, extensions and transport projects (FCAN) [8] and that agreement cost is conversely corresponding to the money related dangers included. The public work of the project is generally awarded to the lowest responsive bid. Over competition results in low bidding and low bidding impact on time, cost, quality and overall performance of the project, therefore it practically needs a study on competition trends with project categorizations and dependency of bidder's involvement $\&$ other factors in bid award. Modification on the current public procurement system of the country to select the appropriate contractors for the execution of development projects like road, bridges, and maintenance related projects.

The category of the project should be separated with respect to type (category of works like general road works, structural works like bridges and culverts and maintenance of roads and bridges to make them serviceable and prolong their life) and basis of sizes of Project. In Road Divisions, bidders bid differently in various categories of contracts according to the nature of works. Numerous researches have been conducted in this area without separating the bid awarding trends based on its type and size of works with the effect of the number of bidder's involvement. Hence, it is necessary to study and analyze to detect and minimize bid-rigging, determine the right level of competition during bidding to achieve better performance in implementing the construction projects, to estimate the bidding amount based on the number of bidders.

\section{RESEARCH OBJECTIVES :}

The objective of this research is to study and analyze to detect and minimize bid-rigging, determine the right level of competition during bidding to achieve better performance in implementing the construction projects, to estimate the bidding amount based on several bidders with types (General Road Construction Works, Structural works like bridges and culvert construction works and maintenance works for road and bridges) and sizes (in terms of initial engineer's cost estimates) of works in roads/bridges projects under road divisions and analyze the relation between numbers of bidder, lowest responsive bidding cost, estimated amount with type and size of projects.

\section{LITERATURE REVIEW :}

Several factors (i.e. nature of work contrasting the technicality and span coverage of the project, bidding requirement, socio-economic conditions, rivalry, need for work, probability of winning, number of bidders, the accuracy of the estimate, amount of data \& information available, etc.) influence a 
contractor's participation in bid and bid awarded price (Hong \& Shum, 2002) [9]. Contractor winning the contract through traditional bidding procedure generally raises dispute and trends to compensate the loss through claims, existing bidding procedure guarantees the lowest cost project but not necessarily the best and higher the number of bidders, higher will be the chance of low bidding $\&$ civil works having a cost estimate up to two million can be awarded to the bidder having lowest bidding price (Bista \& Mishra, 2019) [5].

With 10 to $15 \%$ of Gross domestic product (GDP) in developed countries and up to $20 \%$ in developing countries, $60 \%$ of the annual national budget goes to procurement [5]. The government has increased investment volume on mega projects giving the national identification as "Rastriya Gaurav ka Aayojanaharu". So, Nepalese contractors got some favourable conditions to develop their capacity and got opportunities to take part in several construction projects and came in a position to do all kinds of national construction works like roads, buildings, dams, etc. except mega projects (FCAN) [8]. Public Procurement Act (PPA) [2], 2007 and Public Procurement Regulation (PPR), 2007 are the governing act and regulation for the execution of contract administration by the public sector in our country. Based on PPA (2007) and PPR (2007) [2], Public Procurement Monitoring Office (PPMO) has prepared the standard bidding documents which are followed by the public sector for the executing of the construction project in the public sector. E-bid follows a formal competitive tendering procedure in which several contractors submit bids through electronic media based on complete plans, bill of quantities and specifications (Bista \& Mishra, 2019) [5].

It is considered an innovative bidding method which overcomes the drawbacks of the traditional lowbidding system and emphasizes on the quality of the end product rather than cost alone. The prequalification process of the best value method considers the determination of the capacity of contractors to deliver quality products and not just quantitative financial evaluation. Bista \& Mishra (2019) [5] states that serious low offer technique is supported for sparing a lot of cash and limiting the degree of partiality and defilement and by the utilization of such strategy, discovered a negative effect on contractual worker's benefit, debates/claims, coordination, quality control, venture cost, and span.

Lack of healthy competition i.e. low bidding in contracting is affecting contractors negatively in their financial capacity along with the poor performance of contractors and projects. Contractual workers can endure seriously undervalue change and high-financing costs if installments are postponed. Proprietors ought to be focused on executing installments timely (Regmi \& Mishra, 2017) [10]. Generally, two types of contracting choices among negotiation with contractors and competitive bidding through various bidders by inviting bid are found in practice.

Cartelling involves grouping or association of contractors working jointly to control the price and outcome of bidding to obtain a monopoly in the particular construction sector and dummy companies and the contractor submit bid prices that are very close to each other and pull the average towards their price (Ioannou \& Lou, 1993) [11].The monopoly in the construction business restricts from competing for quality and promotes a certain group of firms only and restricts the entry of new firms who could not cartel for a job regularly (ibid).

Bista and Mishra, (2018) [5] states that the propensity of temporary workers to offer to bring down the offer cost is high in street development undertakings and found that such inclination is significantly higher on account of new development type street ventures in contrast with different kinds like restoration, support, and so forth. Most of the contractor's bid with the bidding price $25 \%-40 \%$ low concerning the engineer's estimate. Contractors generally feel that 5\%-15\% lower amount than the original engineer's estimate is the normal range for bidding to obtain nominal profit in building projects and below that range bid is considered as a low bid.

There is no uniformity in the definition of low bids and abnormally Low Bids (ALBs). In India, the bid is considered a low bid that varies from the estimated rates by more than $25 \%$, even after updating the scheduled rates to match the prevailing cost index. In Taiwan, the complete Bid Price under $80 \%$ of the gauge is viewed as an ALB. As indicated by the National enactment of the United Kingdom low delicate unusually is the one which strays by $10 \%-15 \%$ from the normal cost offered. According to research conducted by Disti (2011 [12]), a tender having a bid price lower than $60 \%$ to the engineer's estimate is considered as an ALB or ALT and Bhattarai (2015) [13] concluded regarding low bidding as result showed that trend of low bidding was higher. The frequency of bid ranging $30 \%-50 \%$ low to the engineer's estimate was the higher. The numbers of bidders are $67.2 \%$ responsible for increasing the percentage below the engineer's estimate and it might be suggested that the equation to calculate the $\%$ 
below Er's estimate with the help of the number of bidders for DRO Nepalgunj is $\mathrm{P}=5.421 \mathrm{~N}-4.199$ and $\mathrm{R}^{2}=0.67$ where $\mathrm{N}=$ no. of bidders and $\mathrm{P}=\%$ below Er's estimate (Bista \& Mishra, 2019) [5].

\section{METHODOLOGY :}

This was an analytical (quantitative inferential approach) research to look up and to be decided on trends nowadays on the bidding process for public procurement. The methodological framework adopted in the course of the study was a review of secondary information sources/ data of respective road division offices (Road Division Butwal \& Shivapur) for consecutive four fiscal years (072-73 to 075-76 contracting record books) with data contract no., initial estimated amount, contract awarded cost, no. of bidders (no. of hard copy \& no. of E-bid) and was analyzed through statistical analysis tools and results were presented through various tables and figures to get percentage below engineers' estimate was found to be positively correlated. Best-fit regression equation was obtained as:

$\mathrm{y}=\mathrm{A}^{*} \mathrm{x}+\mathrm{B}$, where, $\mathrm{y}=\%$ age below engineers' estimate and $\mathrm{A}$ is the number of bidders for a particular contract. The effect of e-bidding on awarded cost is also analyzed by separating hardcopy bid only and bids with e-bid.

\section{Study Area \& Population}

Various accomplished projects, ongoing projects whose procurement has completed already under Road Division Butwal, Rupandehi and Road Division Shivapur, Kapilvastu on consecutive four fiscal years like F/Y 072/73, F/Y 073/74, F/Y 074/75 and F/Y 075/76 were considered for this research study.

\section{Sampling and Data Collection}

This study included all data of the study area for better analysis and results for the given objectives. Overall, 769 completed contract data (526 contract data from road division Butwal \& 243 contract data from road division Shivapur) which has already completed the procurement award phase. The major inputs extracted were the Engineers' Estimate, awarded bid prices, number of bids submitted with no. of hard copy bidding and e-bidding, and were analyzed and conclusions are made.

To analyze, the researcher first categorizes the project contract works into various categories, the first category is types of projects and the second is according to sizes as listed below:

\section{Categorization with TYPES}

- Type A (General Road works): This includes all General road works varying from earthen road works, Drain construction, base, Sub-base works, and all bituminous works.

- Type B (Structural Works): This includes all structural construction works of bridge construction works, culvert construction works which are geographically concentrated but need highly technical expertise.

- Type C (Maintenance Works): This includes all types of road/bridge maintenance works like recurrent maintenance to periodic maintenance works.

\section{Categorization with SIZES}

- Size 1: Projects having engineers estimated to cost less than 2 million with VAT \& contingencies.

- Size 2: Projects having estimated cost equal or more than 2 million and less than 20 million with VAT \& contingencies.

- Size 3: Projects having estimated cost equal or more than 20 million and less than 1 billion with VAT \& contingencies.

\section{DATA ANALYSIS AND PRESENTATION OF DATA :}

After the data collection, the data were categorized based on the type of categorization of procurement/contracting works to general road construction works, structural works like bridges and culvert construction work and road, and bridge maintenance work. The projects were also categorized in terms of project size/estimated amount. Then, Minimum Bid Ratios (AEr):

$\mathrm{AEr}=\frac{\text { MinimumorLowestBidAmountorAwardCost(InGeneralCase) }}{\text { Estimatedcost }} \%$

(1-Aer) were calculated.

For the Co-relation between the number of bidders and lowest responsive cost/final bidding cost (\% below Engineer's Estimate, the researcher carried out Karl Pearson's correlation between the number of bidders and \% below Engineer's Estimate [5]. This correlation was carried out according to the type of the project and size of projects according to the public entity. As DOR carries out mainly Road and bridges project, the combination of RD Butwal and Shivapur was presented in tables and graphs. The number of bidders 
per project for each categorization was also presented which help to conclude the competitive nature of work in the study area.

\section{RESULTS AND DISCUSSIONS :}

Data were analyzed to explore bidding trends, level of competition, nature, and extent of bidders participation in final bid awarding cost and its consequences in low bidding, the effect of e-bidding in road division's project, and co-relation between numbers of bidders \& dependency to percentage below engineers' estimate.

Comparison of Relation between \% no. of Bidders and \%age Below Estimate

It is found from fig. 1 that the maximum (31.1\%) contractors bid at $25-30 \%$ below in fiscal year $074 / 75$ and fiscal year $073 / 74$ the bid with $65-70 \%$ below was also awarded.

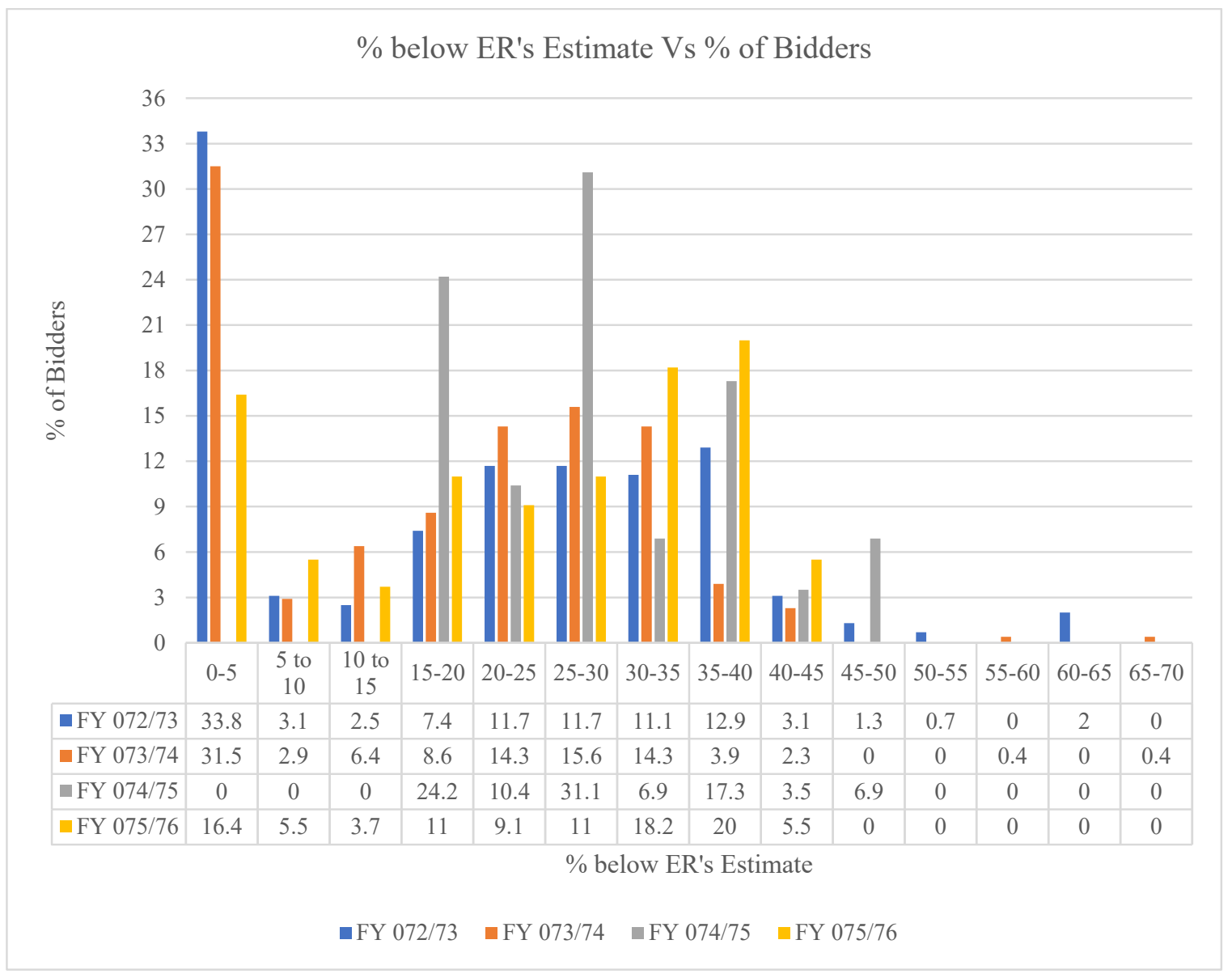

Fig. 1: \% no. of bidder's vs \% below ER's Estimate of 4 FY of Butwal Division

Overall, we can be concluded that maximum bidders want to take their bids at about $15-30 \%$ below the engineer's estimate. Which is the average percentage below of all contracts seen in the division which helped to say that contractors themselves try to get works at a low percentage but with the competition they were forced to make bids low?

\section{Comparison of Relation between \% no. of Bidders and \%age Below Engineer's Estimate:}

It is found from table 1 that the maximum (31.1\%) contractors bid at $25-30 \%$ below in fiscal year $074 / 75$ and fiscal year $073 / 74$ the bid with $65-70 \%$ below was also awarded. In overall it can be concluded that maximum bidders want to take their bids at about $15-30 \%$ below than the engineer's estimate in Butwal Division and maximum $(25.00 \%)$ contractors bid at $15-20 \%$ below in fiscal year $075 / 76$ and in overall we can conclude that maximum bidders want to take their bids at about $15-30 \%$ below than the engineer's 
estimate in Shivapur Division. Bidders should bid in between 20-35\% below the engineer's estimate to get work in hand.

From the fig. 2, the average percentage below of bidding amount and an average number of bidders are worked out and found as in Butwal division it is found that in FY 072/73 average number of the bidder is 4.61 and average \% below is 19.89 similarly in FY $073 / 74$ average number of the bidder is 3.31 and average \% below is 18.20 , in FY $074 / 75$ average number of the bidder is 6.79 and average \% below is 28.53 , in FY $075 / 76$ average number of the bidder is 5.44 and average $\%$ below is 23.95 . And hence it is found that the average number of bidders is directly proportional to the $\%$ below of bidding cost i.e. if a higher number of bidders are present in any project, the possibility of more $\%$ below increases.

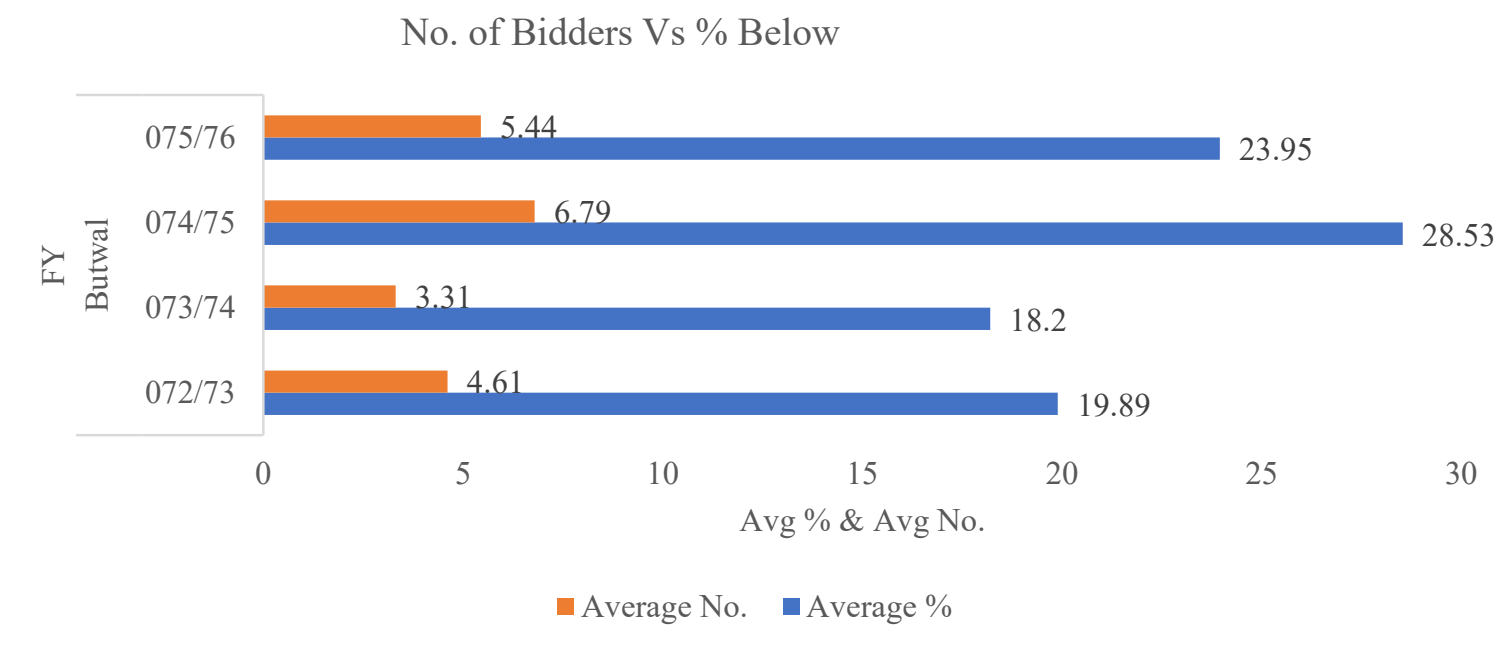

Fig. 2 : Average Percentage below average number of bid Submission in Butwal division

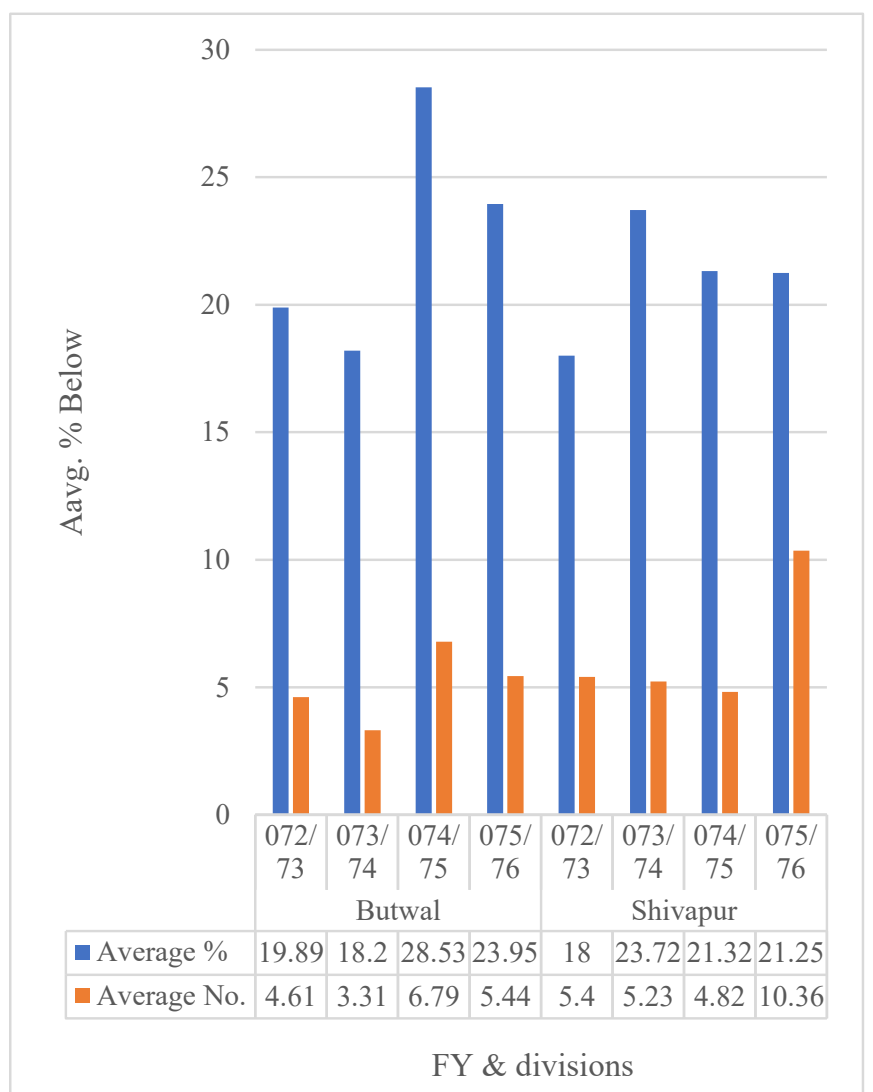

Fig. 3 : Average Percentage below-average number of bid Submission in the overall of both divisions 


\section{Overall Comparison of Both Divisions :}

Average percentage below of bidding amount and the average number of bidders are worked out and found as in both divisions Butwal \& Shivapur divisions it is found that the average number of bidders is directly proportional to the $\%$ below of bidding cost i.e. if a greater number of bidders are present in any project, the possibility of more $\%$ below increases.

According to a study made by Bista\& Mishra, [5], for Nepalgunj and Mahendranagar road divisions analysis of bidding data of three fiscal year reveals that number bidders were $67 \%$ responsible for low bidding. The remaining 33\% were other causes for low bidding. A study to determine the causes of low bidding other than the number of bidders was beyond the scope of research. It can be concluded that the association between the number of bidders and the percentage below the engineer's estimate is strong (coefficient of correlation is 0.82) i.e. increase in the number of bidders increases the percentage below the engineer's estimate (promote low bid).

Upon comparison of both division's contract data over the four fiscal years i.e. 072/73, 073/74, 074/75, and 075/76 of both Butwal division and Shivapur division. In Butwal division FY 072/73 average \% below is $19.89 \%$ that of engineer's estimate and similarly from above table average of whole division's 4 years data gave $22.65 \%$ below engineers estimate.

Table 1 : Comparison of both division's average \% below and Avg. no. of Bidders

\begin{tabular}{|c|c|c|c|c|}
\hline & \multicolumn{4}{|c|}{ Butwal division } \\
\hline FY & $\%$ below & Avg. of division & Avg. no. of bidders & Avg. of division \\
\hline $072 / 73$ & 19.89 & \multirow{4}{*}{22.65} & 4.61 & \multirow{4}{*}{5.04} \\
\hline $073 / 74$ & 18.20 & & 3.31 & \\
\hline $074 / 75$ & 28.53 & & 6.79 & \\
\hline $075 / 76$ & 23.95 & & 5.44 & \\
\hline
\end{tabular}

In Shivapur division FY 072/73 average \% below is $18.00 \%$ that of engineer's estimate and similarly from above table average of whole division's 4 years data gave $21.07 \%$ below engineers estimate.

Similarly, on comparison of both divisions contract data over the four fiscal years i.e. 072/73, 073/74, 074/75 and 075/76 of both Butwal division and Shivapur division. In Butwal division FY 072/73 average number of bidders is found as 4.61 per project and similarly from above table average of the whole division's 4 years data gave 5.04 number of bidders per project.

In Shivapur division FY 072/73 average number of bidders is found as 5.40 per project and similarly from above table average of the whole division's four years data gave 6.45 number of bidders per project. From the above table 1 comparison it is found that the average \% below that of Butwal division is the higher and in terms of bidder number average number is higher in Shivapur division. The reason, in this case, might be in the Butwal division project award number is highest more number of the project leads to the lesser average number of bidders per project but a competition to get contract seems the same in both divisions. On an average above $20 \%$ below tender only gets the contract in hand.

\section{Comparison of Relation Between No. of Bidders and \%age Below Engineer's Estimate :}

From fig. 4, the correlation between the number of bidders and the percentage below engineer's estimates is positive (coefficient of correlation). Data reveals that there is a significant correlation between these two variables. Simply it can be stated that, when the number of bidders increases, then the percentage below the engineer's estimate also increases. On another way to promote low bidding, the number of bidders was about $37.00 \%$ (regression coefficient 0.61 ) responsible. It showed the general trend of bidding i.e. increasing the number of bidders increases the percentage below the engineer's estimate.

According to a study made by Bista \& Mishra, [5] for Nepalgunj and Mahendranagar road divisions analysis of bidding data of three fiscal years revealed that the number of bidders is $67 \%$ responsible for low bidding. The remaining 33\% are other causes of low bidding. Study to determine the causes of low bidding other than the number of bidders is beyond the scope of research. It can be concluded that the association between the number of bidders and the percentage below the engineer's estimate is strong (coefficient of correlation is 0.82) i.e. increase in the number of bidders increases the percentage below 
the engineer's estimate (promote low bid).

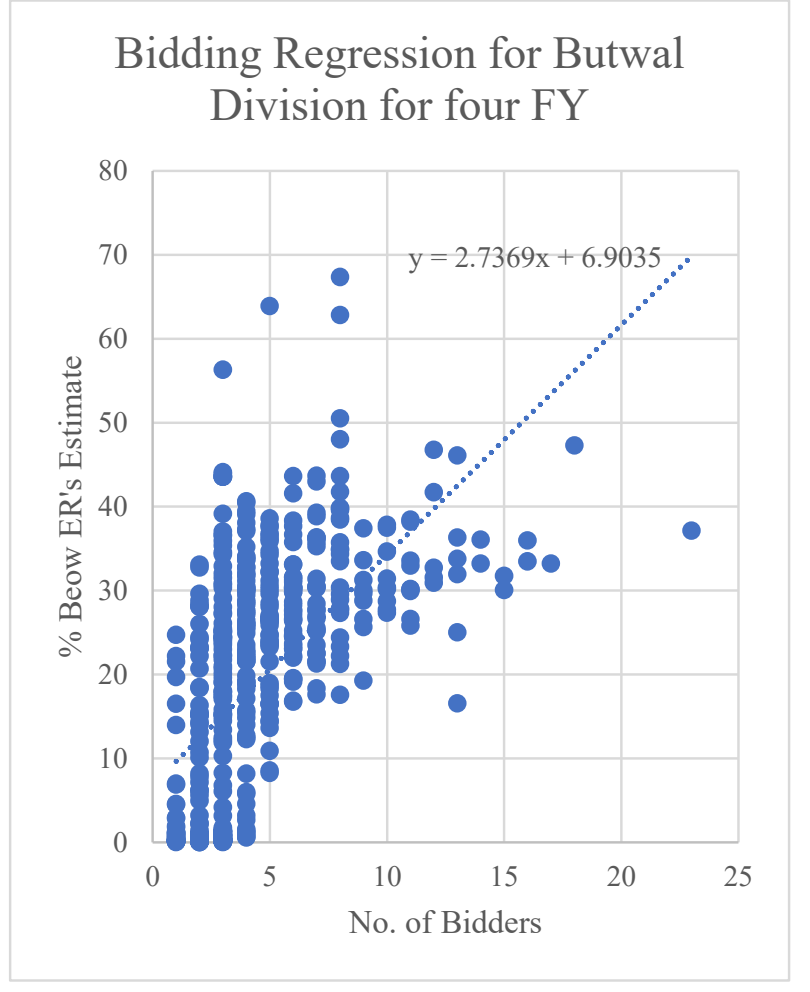

Fig. 4: Regression for whole Four years of Butwal division

From the comparison made by the researcher and Bista \& Mishra [5], it is found that the relation between no. of bidders and \%age below engineer's estimate is more closely related or more dependable to no. of contractors occurred in Nepalgunj and Mahendra Nagar than in Butwal and Shivapur divisions. The comparison is done as the study made by Bist and Mishra, [5], is also of road division's projects where the researcher thought the results and contracting practices of bidders would be similar.

Correlation between the number of bidders and the percentage below the engineer's estimates is positive (coefficient of correlation). Data reveals that there is a significant correlation between these two variables. Simply it can be stated that, when the number of bidders increases, then the percentage below engineer's estimate also increases. On another way to promote low bidding, the number of bidders is about $45.00 \%$ (regression coefficient 0.67 ) responsible. It shows the general trend of bidding i.e. increasing the number of bidders increases the percentage below the engineer's estimate.

\section{Comparison of the relation between no. of bidders and \%age below engineer's estimate Between} Two Divisions :

Upon comparison of both charts above \& the data reveals that the association between contractor number and \%age below engineer's estimate is more closely correlated in the Shivapur division than in the Butwal division. 


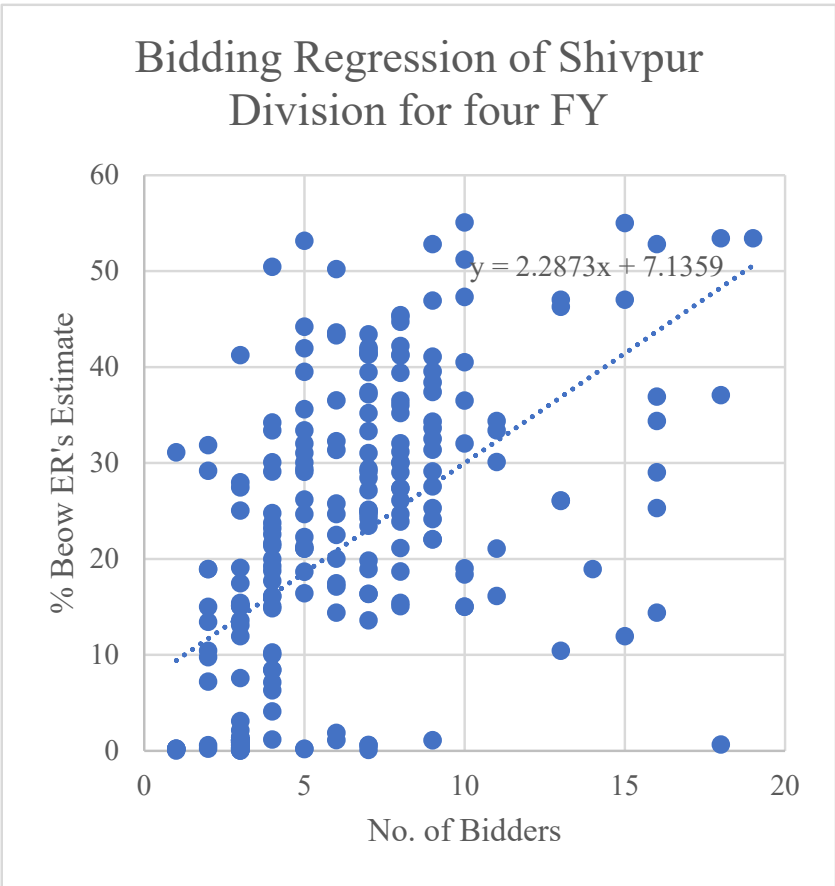

Fig. 5 : Regression chart for the whole four FY of Shivapur division

Table 2 : Comparison of the relation between no. of bidders and \%age below the engineer's estimate Between Two Divisions:

\begin{tabular}{|c|c|c|c|c|}
\hline & \multicolumn{2}{|c|}{ Butwal division } & \multicolumn{2}{|c|}{ Shivapur Division } \\
\hline FY & Regression (R2) & Average regression & Regression (R2) & Average regression \\
\hline $072 / 73$ & 0.3 & \multirow{4}{*}{0.37} & 0.4 & \multirow{4}{*}{0.45} \\
\hline $073 / 74$ & 0.3 & & 0.4 & \\
\hline $074 / 75$ & 0.4 & & 0.6 & \\
\hline $075 / 76$ & 0.3 & & 0.3 & \\
\hline
\end{tabular}

Comparison of Relation between No. of Bidders and \%age Below Engineer's Estimate with Types of Projects :

From table 2, it can be stated that in Butwal division there is consistent relation between no. of bidders and $\%$ age below the engineer's estimate than that of Shivapur division and in general, also we can see the positive and directly proportional relation between the no. of bidders and \% below that of engineers estimate. It can also be seen that in type A projects there is more concentration of bidders than that of Type B \& Type C projects in both divisions.

Table 3 : Comparison of the relation between no. of bidders and \%age below the engineer's estimate with types of projects:

\begin{tabular}{|c|c|c|c|c|c|c|c|c|c|}
\hline Div. & $\begin{array}{l}\text { Fiscal } \\
\text { years }\end{array}$ & $\begin{array}{l}\text { Type of } \\
\text { projects }\end{array}$ & $\begin{array}{l}\% \\
\text { below }\end{array}$ & $\begin{array}{l}\text { Avg. } \\
\text { Bidders }\end{array}$ & Div. & $\begin{array}{l}\text { Fiscal } \\
\text { years }\end{array}$ & $\begin{array}{l}\text { Type of } \\
\text { projects }\end{array}$ & $\begin{array}{l}\% \\
\text { below }\end{array}$ & $\begin{array}{l}\text { Avg. } \\
\text { Bidders }\end{array}$ \\
\hline \multirow{5}{*}{ Butwal } & \multirow{3}{*}{$072 / 73$} & $\mathrm{~A}$ & 18.19 & 4.25 & \multirow{5}{*}{ Shivapur } & \multirow{3}{*}{$072 / 73$} & $\mathrm{~A}$ & 17.81 & 5.56 \\
\hline & & $\mathrm{B}$ & 19.81 & 6.23 & & & B & 11.25 & 4.5 \\
\hline & & $\mathrm{C}$ & 27.69 & 5.3 & & & $\mathrm{C}$ & 20.36 & 5.29 \\
\hline & \multirow{2}{*}{$073 / 74$} & $\mathrm{~A}$ & 17.56 & 3.15 & & \multirow{2}{*}{$073 / 74$} & $\mathrm{~A}$ & 23.61 & 4.79 \\
\hline & & B & 13.21 & 3.4 & & & B & 26.67 & 8.14 \\
\hline
\end{tabular}


International Journal of Management, Technology, and Social

SRINIVAS

Sciences (IJMTS), ISSN: 2581-6012, Vol. 4, No. 2, October 2020

PUBLICATION

\begin{tabular}{|c|c|c|c|c|c|c|c|}
\hline & $\mathrm{C}$ & 29.23 & 4.7 & & $\mathrm{C}$ & 23.5 & 6.4 \\
\hline \multirow{3}{*}{$074 / 75$} & A & 34.58 & 8.45 & \multirow{3}{*}{$074 / 75$} & $\mathrm{~A}$ & 24.69 & 4.6 \\
\hline & B & - & - & & B & 25 & 7 \\
\hline & $\mathrm{C}$ & 24.26 & 5.24 & & $\mathrm{C}$ & 17.5 & 3.88 \\
\hline \multirow{3}{*}{$075 / 76$} & A & 29.17 & 6.41 & \multirow{3}{*}{$075 / 76$} & A & 25.71 & 11.57 \\
\hline & B & - & - & & B & - & - \\
\hline & $\mathrm{C}$ & 18.93 & 4.5 & & $\mathrm{C}$ & 16.69 & 9.14 \\
\hline
\end{tabular}

Comparison of regression among the project Types :

In this section, all the projects under different road divisions are categorized with types and three types of regression analysis were done to find out the dependency on percentage below engineer's estimate with the number of bidders per project.

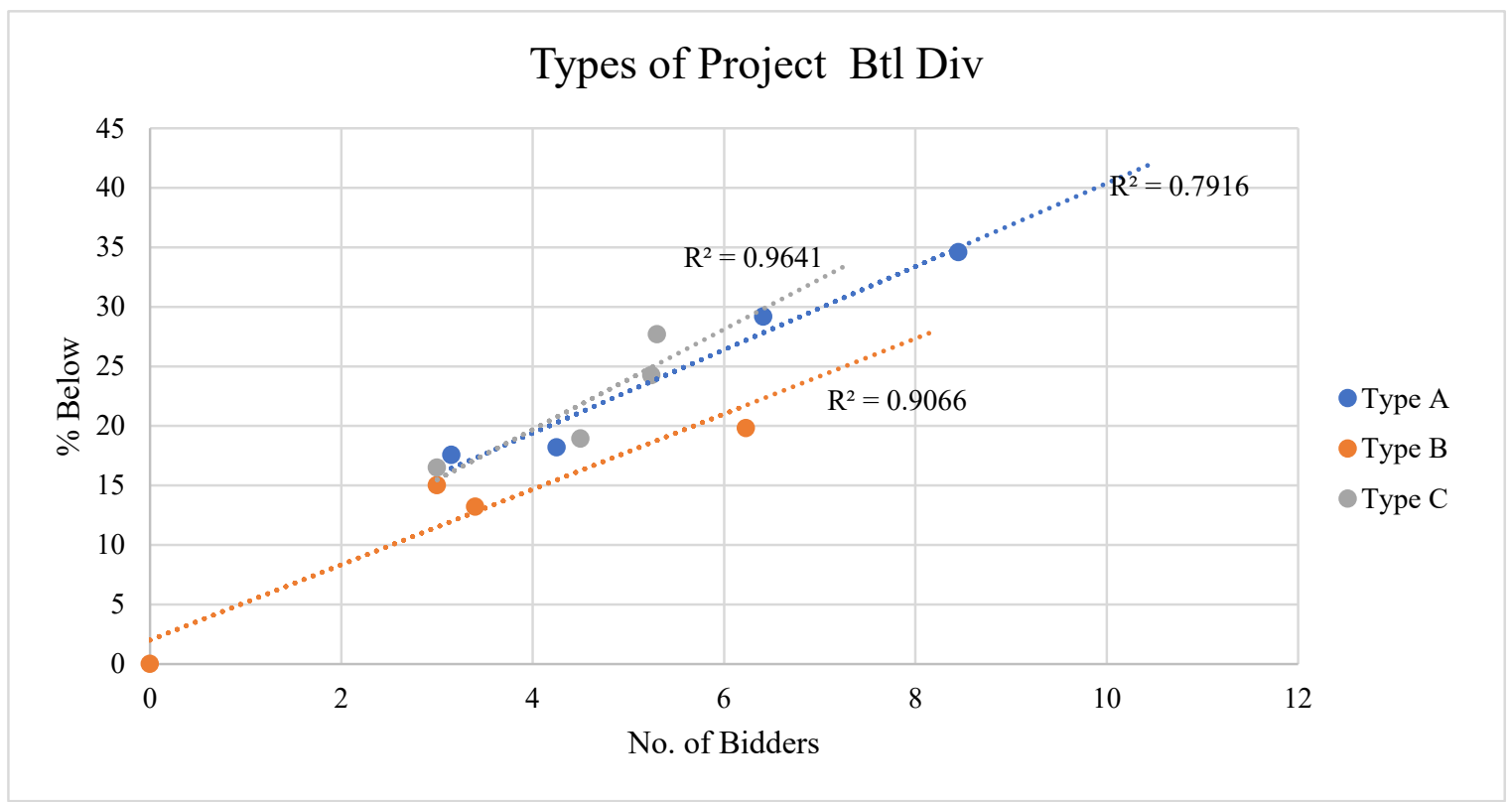

Fig. 6 : Regression chart for the project Types of Butwal division

Figure 6 above can be stated that the projects categorization and their effect on the percentage below engineers estimate was found $79.16 \%$ for type A projects on Butwal division, $90.66 \%$ for type B projects and $96.41 \%$ for type C projects and found and from table 5 it was stated that, in Shivapur Division it was found that the type A project is dependent by $72.60 \%, 96.80 \%$ for type B projects and for type C projects it came $57.8 \%$ which were much more significant relationship than the whole projects regression. Hence it revealed that the specific categorization study demonstrates the more dependency on projects percentage below than the whole analysis.

Table 4 : Comparison of regression among the project Types of both divisions

\begin{tabular}{|c|c|c|c|c|c|c|c|c|c|c|c|}
\hline \multicolumn{12}{|c|}{ Type categorization of Projects with \% below vs no. of bidders } \\
\hline \multicolumn{12}{|c|}{ Butwal div } \\
\hline & No.of Bid & $\%$ below & R2 & & No.of Bid & $\%$ below & R2 & & No.of Bid & $\begin{array}{l}\% \\
\text { below }\end{array}$ & R2 \\
\hline \multirow{3}{*}{ A } & 4.25 & 18.19 & \multirow{3}{*}{0.964} & \multirow{3}{*}{ B } & 6.23 & 19.81 & \multirow{3}{*}{0.906} & \multirow{3}{*}{$\mathrm{C}$} & 5.3 & 27.69 & \multirow{3}{*}{0.791} \\
\hline & 3.15 & 17.56 & & & 3.4 & 13.21 & & & 3 & 16.5 & \\
\hline & 8.45 & 34.58 & & & 3 & 15 & & & 5.24 & 24.26 & \\
\hline
\end{tabular}

Anjay Kumar Mishra, et al, (2020); www.srinivaspublication.com 
International Journal of Management, Technology, and Social

\begin{tabular}{|c|c|c|c|c|c|c|c|c|c|c|c|}
\hline & 6.41 & 29.17 & & & 0 & 0 & & & 4.5 & 18.93 & \\
\hline \multicolumn{12}{|c|}{ Shivapur div } \\
\hline \multirow{4}{*}{ A } & 5.56 & 17.81 & \multirow{4}{*}{0.726} & \multirow{4}{*}{ B } & 4.5 & 11.25 & \multirow{4}{*}{0.968} & \multirow{4}{*}{$\mathrm{C}$} & 5.29 & 20.36 & \multirow{4}{*}{0.578} \\
\hline & 4.79 & 23.61 & & & 8.14 & 26.67 & & & 6.4 & 23.5 & \\
\hline & 0 & 0 & & & 7 & 25 & & & 3.88 & 17.5 & \\
\hline & 11.57 & 25.71 & & & 0 & 0 & & & 9.14 & 16.69 & \\
\hline
\end{tabular}

Comparison of Relation between No. of Bidders and \%age Below Engineer's Estimate with Sizes of Projects :

From table 5, it can be said that in both divisions there is consistent relation between no. of bidders and $\%$ age below the engineer's estimate, and in general also we can see the positive and directly proportional relation between the no. of bidders and \% below that of engineers estimate. It can also be seen that in Size 1 projects are very fewer number of projects and the intention of bidders was on higher. So that less number of bidders bid in such projects but size 2 projects were awarded in high numbers in divisions and these projects are middle size projects with similar nature and less expertise requires and hence more bidders were concentrated in such projects and again it can be seen that Size 3 projects were more technical expertise demanded projects and for this technical as well as financial resources required the most. So that size 3 projects were bid by only a few bidders. But in FY 075/76 of both divisions, there are very few projects like size 3 and more bidders were seen to compete and the result of that reason \%age below for this year was also found high.

Table 5 : Comparison of relation between no. of bidders and \%age below engineer's estimate with Sizes of projects:

\begin{tabular}{|c|c|c|c|c|c|c|c|c|c|}
\hline Division & $\begin{array}{l}\text { Fiscal } \\
\text { years }\end{array}$ & $\begin{array}{l}\text { Type of } \\
\text { projects }\end{array}$ & $\begin{array}{l}\% \\
\text { below }\end{array}$ & $\begin{array}{l}\text { Avg. } \\
\text { Bidders }\end{array}$ & Divisions & $\begin{array}{l}\text { Fiscal } \\
\text { years }\end{array}$ & $\begin{array}{l}\text { Type of } \\
\text { projects }\end{array}$ & $\begin{array}{l}\% \\
\text { below }\end{array}$ & $\begin{array}{l}\text { Avg. } \\
\text { Bidders }\end{array}$ \\
\hline \multirow{12}{*}{ Butwal } & \multirow{3}{*}{$072 / 73$} & 1 & 10.19 & 3.05 & \multirow{12}{*}{ Shivpur } & \multirow{3}{*}{$072 / 73$} & 1 & 17.25 & 5.4 \\
\hline & & 2 & 32.41 & 6.75 & & & 2 & 21 & 5.4 \\
\hline & & 3 & 24.4 & 6.24 & & & 3 & - & - \\
\hline & \multirow{3}{*}{$073 / 74$} & 1 & 14.54 & 2.99 & & \multirow{3}{*}{$073 / 74$} & 1 & 24.13 & 5.16 \\
\hline & & 2 & 23.92 & 3.67 & & & 2 & 24.22 & 5.48 \\
\hline & & 3 & 14.75 & 3.43 & & & 3 & 14.5 & 4.6 \\
\hline & \multirow{3}{*}{$074 / 75$} & 1 & 24.17 & 5.13 & & \multirow{3}{*}{$074 / 75$} & 1 & 16.5 & 3.2 \\
\hline & & 2 & 34.77 & 8.64 & & & 2 & 25.15 & 5.75 \\
\hline & & 3 & 27.5 & 8.33 & & & 3 & 18.93 & 3 \\
\hline & \multirow{3}{*}{$075 / 76$} & 1 & 12.5 & 3.8 & & \multirow{3}{*}{$075 / 76$} & 1 & 16.67 & 8 \\
\hline & & 2 & 27.33 & 4.33 & & & 2 & 22 & 10.7 \\
\hline & & 3 & 31 & 11.2 & & & 3 & 27.5 & 14 \\
\hline
\end{tabular}

\section{Relation of E-Bidding and Low Bidding}

Analysis of bidding data of fiscal year 2073/74 of DRO Butwal has been done to understand the relationship between E-Bidding and Low Bidding. It is done by sorting out the bidding data into two groups. One having with electronic submission and the other having without electronic submission. Out of 315 contracts, 27 contracts are with e-bids and 288 contracts are without e-bids. Considering the same environment in Division Road Office for submission of all 315 bids. Calculation of average percentage below engineers' estimate in both cases and taking $15 \%$ percentage below engineers' estimate as a threshold of the low bid and normal bid are done as given in table 6 below. 
International Journal of Management, Technology, and Social

Table 6 : Average Percentage below Engineers' Estimate with e-bid Submission

\begin{tabular}{|c|c|c|c|c|c|}
\hline $\mathrm{SN}$ & $\begin{array}{c}\text { \%below engineer's } \\
\text { estimate }\end{array}$ & Mid value $(\mathrm{X})$ & $\begin{array}{l}\text { No. of contracts } \\
\text { (f) }\end{array}$ & $\mathrm{U}=(\mathrm{X}-\mathrm{A}) / 5$ & Uxf \\
\hline 1 & $0-5$ & 2.5 & 0 & -2.5 & 0 \\
\hline 2 & $5-10$ & 7.5 & 0 & -1.5 & 0 \\
\hline 3 & $10-15$ & 12.5 & 0 & -0.5 & 0 \\
\hline 4 & $15-20$ & 17.5 & 1 & 0.5 & 0.5 \\
\hline 5 & $20-25$ & 22.5 & 5 & 1.5 & 7.5 \\
\hline 6 & $25-30$ & 27.5 & 10 & 2.5 & 25 \\
\hline 7 & $30-35$ & 32.5 & 10 & 3.5 & 35 \\
\hline 8 & $35-40$ & 37.5 & 0 & 4.5 & 0 \\
\hline 9 & $40-45$ & 42.5 & 1 & 5.5 & 5.5 \\
\hline 10 & $45-50$ & 47.5 & 0 & 6.5 & 0 \\
\hline 11 & $50-55$ & 52.5 & 0 & 7.5 & 0 \\
\hline 12 & $55-60$ & 57.5 & 0 & 8.5 & 0 \\
\hline \multirow[t]{2}{*}{13} & $60-65$ & 62.5 & 0 & 9.5 & 0 \\
\hline & & Sum & 27 & & 73.5 \\
\hline \multicolumn{6}{|c|}{ Average percentage below engineers' estimate $(y)=A+\left(\sum U \times f / \sum f\right) \times h \quad$ in $\%$} \\
\hline & & 28.6 & $\%$ & & \\
\hline
\end{tabular}

The average percentage below engineers' estimate in case of with e-bid submission is found to be $28.61 \%$ below engineers' estimate. Normal bids and low bids were identified in this case and out of 27 contracts, 17 bids were found as normal bids and 10 bids were found as low bids i.e. $48.15 \%$ were normal and $51.85 \%$ were low bids.

In other case, data were acquired having zero E-Bid and the threshold of a low bid is calculated as Average percentage below engineers' estimate $(\mathrm{y})=\mathrm{A}+\left(\sum \mathrm{U} \times \mathrm{f} / \sum \mathrm{f}\right) \times \mathrm{h}$ in $\%$ is $17.05 \%$

Out of 288, 139 are normal and 149 are low bid i.e. $48.26 \%$ are normal and $51.74 \%$ is low bid.

Under similar circumstances, in the first sets of data having E-Bids, the number of low bids is much more than in the second sets of data having no E-Bids. Hence, it can be stated that based on the analysis of bidding data, E-Bidding necessarily promotes the competition. It can be interpreted this result as EBidding increases competition among the bidders.

Table 7 : Summary of below Engineers' Estimate without e-bid Submission

\begin{tabular}{|c|c|c|c|c|c|}
\hline \multirow{2}{*}{ Work Type } & \multicolumn{5}{|c|}{ DRO, Butwal } \\
\cline { 2 - 7 } & $\mathrm{y}$ & \multicolumn{2}{|c|}{ Normal bid } & \multicolumn{2}{c|}{ Low bid } \\
\cline { 2 - 7 } & $\%$ & No. & $\%$ & No. & $\%$ \\
\hline With E-bid & 28.61 & 13 & 48.15 & 14 & 51.85 \\
\hline Without E-Bid & 17.05 & 139 & 48.26 & 149 & 51.74 \\
\hline & Avg. No. of bid & \multicolumn{2}{|c|}{ Comp. Bid } & \multicolumn{2}{c|}{ Not comp. Bid } \\
\hline With E-bid & 5.74 & 17 & 62.96 & 10 & 37.04 \\
\hline Without E-Bid & 3.08 & 109 & 37.98 & 178 & 62.02 \\
\hline
\end{tabular}

It is also found that whenever there is e-bidding occurs in any project there is no or very low possibility for bids collusion and collusion of bids occurs mostly in mutual understanding among the bidders. So that researcher keen to give the view on the promotion of e-bidding for better procurement management and with promoting e-bidding there was low bidding which can be mitigated by improving the bid awarding systems. 


\section{CONCLUSIONS :}

On data analysis, to get the actual relation between the number of bidders with percentage below engineers to estimate in the bidding process the regression analysis was done making the percentage below is a dependent variable. Where the researcher found that in both divisions there is a significant relationship between numbers of bidders for the bids to become low. With the regression study among type categorization much more significant relation was found than the overall projects inside road divisions. The introduction of e-bidding in the tendering process causes bids to be low as $28.61 \%$ below where no e-bidding contracts only bid $17.05 \%$ low and also there was no or very less collusive in case of e-bidding introduced. So, e-bid reduced collusive bidding but promotes low bidding and researcher suggests that promotion of e-bidding for easy and better contracting practices but low bidding there should be alternative methods which could be enforced through amendment and strong implementation of existing rules and regulations, adopting the other method of contract award.

\section{RECOMMENDATIONS :}

It should be asked the contractors who take the project with low bidding for the method of statement, work schedule, and clarification for low bidding and promotion of e-bidding helps bids not to be more collusive and to be a more competitive and extra technological advance on the e-bidding system from bid awarding to e-payment to contractors may also help in fair practice. A Study on the effects of collusive bidding on the project performance of different categories of works should be continued.

\section{ACKNOWLEDGEMENTS :}

Thanks to Lumbini Engineering, Management \& Science College, affiliated to Pokhara University for this opportunity to accomplish such type of research for enhancing my academic as well as professional career\& both road divisions and concerned respected senior divisional engineers for providing research data without which this work would not have been completed.

\section{REFERENCES:}

[1] GoN, (2007). 2073 B.S. The Public Procurement Act first ammendment, 2063. Kathmandu: Law Books Management Board of Nepal. Available at: http://www.lawcommission.gov.np/en/downloads

[2] GoN, (2019). 2076B.S. Eighth Amendment of Public Procurement Regulation, 2076. Kathmandu. Available at : http://www.lawcommission.gov.np/en/downloads

[3] Bahadur, K. C. M., \& Mishra, A. K. (2019). Bidding Trends of Contracts based on Types and Sizes of Projects under Road Divisions Butwal and Shivapur. J Adv Res Const Urban Arch, 4(3\&4), 7-16. DOI: https://doi.org/10.24321/2456.9925.201905

[4] Mishra A. K., \& Mallik K. (2017). Factors and Impact of Risk Management Practice on success of Construction Projects of Housing Developers, Kathmandu, Nepal. International Journal of Sciences: Basic and Applied Research (IJSBAR), 36(7), 206-232.

[5] Bista, D. B. \& Mishra, A. K. (2019). Bidding Trend and its Effects in Implementation on Road Projects of Division Road Offices of Department of Roads, Nepal. Int J Adv Res Civil Stru Engr, 2(1), 1-9.

[6] Mishra, A. K. (2018). Assessment of Human Resource Capacity of Construction Companies in Nepal. $J$ Adv Res Jour Mass Comm, 5(4), 14-25.

[7] Mishra, A. K. (2019). Implementation Status of Value Management in Project Management Practice in Nepal. International Journal of Management Studies, 6(1). 92-108.

[8] FCAN, Federation of Contractor's Associations of Nepal(FCAN). [Online] Available at : http://nepalconstructions.com/challenges-and-prospects-of-nepalese-construction-industry/

[9] Hong, H. and Shum, M. (2002). Increasing Competition and the Winner's Curse: Evidence from Procurement. Review of Economic Studies, 69(4), 871-898.

[10] Mishra A. K., Regmi U. (2017). Effects of Price Fluctuation on the Financial Capacity of "Class A" Contractors. International Journal of Creative Research Thoughts, 5(4), 1920 -1937. 
International Journal of Management, Technology, and Social

[11] Ioannou, P. G., and Awwad, R. E., (2010). Below-Average Bidding Method. Construction Engineering and Management, 136(9), 143-148.

[12] Disti, R. K., (2011). Review of Bidding Trend in Construction Tenders for the purpose of amendment in Public Procurement Legislation of Nepal. Available at www.ppmo.gov.np. Accessed date January 10, 2014.

[13] Bhatta, I., (2014). Issues Related to Selection of Contractors in Public Construction Procurement. Rural Infrastructure, 5(5), 184-189.

$* * * * * * * * * * * * *$ 